\title{
Agronomic Executability of Barley under a Combined Approach of Nutrient Management in Punjab
}

\author{
Ravinder Singh", Kamalesh Kumar and Harpreet Singh \\ Department of Agronomy, G.S.S.D.G.S. Khalsa College, Patiala-147001, India \\ *Corresponding author
}

\section{A B S T R A C T}

\begin{tabular}{l} 
Ke y w o r d s \\
$\begin{array}{l}\text { Barley, Farmyard } \\
\text { manure, Poultry } \\
\text { manure and Rhiz, }\end{array}$ \\
Article Info \\
$\begin{array}{l}\text { Accepted: } \\
\text { 15 August } 2020 \\
\text { Available Online: } \\
\text { 10 September } 2020\end{array}$ \\
\hline
\end{tabular}

A field trail was carried out at Campus for Research and Advanced Studies, Dhablan, G.S.S.D.G.S Khalsa College, Patiala during the Rabi season of 2017-18. The field trial was laid out in randomized block design with eleven treatments $\mathrm{T}_{1}$ : (Control), $\mathrm{T}_{2}:(100 \%$ $\mathrm{RDF}), \mathrm{T}_{3}:(50 \% \mathrm{RDF}+\mathrm{FYM} 5 \mathrm{t} / \mathrm{ha}), \mathrm{T}_{4}:(50 \% \mathrm{RDF}+\mathrm{FYM} 10 \mathrm{t} / \mathrm{ha}), \mathrm{T}_{5}:(50 \% \mathrm{RDF}+$ FYM 10 t/ha + PM 2 t/ha), T $_{6}$ : (50\% RDF + FYM 10 t/ha + PM 2 t/ha + Rhiz.), $\mathrm{T}_{7}:(50 \%$ RDF + FYM 5 t/ha + PM 2 t/ha + Rhiz. + VC 2 t/ha), $\mathrm{T}_{8}:(100 \%$ RDF (NPK) + FYM 5 t/ha), $\mathrm{T}_{9}:(100 \%$ RDF + FYM 5 t/ha + PM 2 t/ha), T 10 : (100\% RDF + FYM 5 t/ha + PM 2 t/ha + Rhiz.), $\mathrm{T}_{11}:(100 \% \mathrm{RDF}+\mathrm{FYM} 5 \mathrm{t} / \mathrm{ha}+\mathrm{PM} 2 \mathrm{t} / \mathrm{ha}+$ Rhiz. + VC $2 \mathrm{t} / \mathrm{ha})$ in three replications. Application of 100\% RDF + FYM 5 t/ha + PM 2 t/ha + Rhiz. + VC 2 t/ha significantly increased growth, yield attributes and yield of barley. Significantly higher net returns and benefit cost (1.43) were observed with the application of 100\% RDF + FYM 5 $\mathrm{t} / \mathrm{ha}+\mathrm{PM} 2 \mathrm{t} / \mathrm{ha}+$ Rhiz. + VC $2 \mathrm{t} / \mathrm{ha}$. However, benefit cost ratio remained at par with the application of $100 \%$ RDF + FYM 5 t/ha + PM 2 t/ha + Rhiz. (1.40) and also in $100 \%$ RDF + FYM 5 t/ha + PM 2 t/ha (1.37).

\section{Introduction}

Barley (Hordeum vulgare L.) is one of the leading cereal crops in the world next to wheat, rice, and maize and the most dependable crop in alkali soils and areas where frost or drought occurs. The major barley producing countries are China, Russia, Germany, the USA, Canada, India, Turkey, and Australia. The major use of barley grain is in brewing industries for manufacturing malt which is used to make beer, industrial alcohol, whiskey, malt syrups, brandy, malted milk, vinegar, and yeast. Barley is usually used as food for human beings and feed for animals and poultry. It is a very nutritious and rich source of vitamin B complex and protein of superior quality. Each $100 \mathrm{~g}$ of barley grain contains $9.9 \mathrm{~g}$ protein, $1.2 \mathrm{~g}$ fat, $77 \mathrm{~g}$ carbohydrates, $29 \mathrm{mg}$ calcium, $2.5 \mathrm{mg}$ iron, and $31 \mathrm{mg}$ vitamin B. It is used as food grain cereal, fodder and is also valuable input for extracting malt to be utilized in brewing, distillation, baby foods, cocoa malt drinks, and ayurvedic medicines. Barley having low water requirements as compared to wheat offers good scope for diversification in Rabi season. In Punjab, Barley is grown on an area of 11 thousand hectares with a production of 39 thousand tonnes and productivity of 35.82 
$\mathrm{q} /$ ha (Anonymous 2016). The introduction and use of dual-purpose crops purposefully bred to prioritize both grains for human consumption and fodder for livestock, has proven to be a successful strategy for augmenting fodder during lean periods. Barley, an important cereal with its wider adaptability to different biotic and abiotic circumstances is best fit under this Food-cumFodder Production System for the reason that if barley is cut close to the ground before the development of second leaf node, the crop regenerates and goes on producing a grain yield similar to uncut crop with fodder as a bonus. Besides other factors, nutritional supply may be crucial for success as well as the profitable cultivation of Barley. Nitrogen is the main constituent of chlorophyll and amino acids which are precursors to protein.

Grain yield and grain protein are characteristics strongly related to available nitrogen (Grant 2000). Integrated use of chemical fertilizers with organic manures could be quite promising in maintaining higher productivity and providing greater stability in crop production. Despite its industrial importance, surplus barley grains find its use as concentrate feed for livestock and poultry. Its straw and husk are good quality roughages for cattle and are used for preparing compost and litter bedding. Hence, there is a great scope of recycling crop waste in cattle and poultry enterprises.

Recycling of organic wastes is not an only ecological necessity but in a country like ours, it is an economical compulsion also since India produces about 363 million tonnes of wastes annually from all field crops (Chaudhary et al., 2004). There is plenty of scopes to work on this aspect to develop better agro-techniques for the production of dual-purpose barley concerning integrated nutrient management.

\section{Materials and Methods}

The study was carried out at Campus for Research and Advanced Studies, Dhablan, G.S.S.D.G.S Khalsa College, Patiala during the Rabi season of 2017-18. The field trial was laid out in randomized block design with eleven treatments $\mathrm{T}_{1}$ : (Control), $\mathrm{T}_{2}$ : $(100 \%$ $\mathrm{RDF}), \mathrm{T}_{3}:(50 \% \mathrm{RDF}+\mathrm{FYM} 5 \mathrm{t} / \mathrm{ha}), \mathrm{T}_{4}$ : (50\% RDF + FYM 10 t/ha), $\mathrm{T}_{5}:(50 \% \mathrm{RDF}+$ FYM 10 t/ha + PM 2 t/ha), $\mathrm{T}_{6}:(50 \% \mathrm{RDF}+$ FYM 10 t/ha + PM 2 t/ha + Rhiz. $), \mathrm{T}_{7}:(50 \%$ RDF + FYM 5 t/ha + PM 2 t/ha + Rhiz. + VC 2 t/ha), $\mathrm{T}_{8}$ : (100\% RDF (NPK) + FYM 5 t/ha), T9: (100\% RDF + FYM 5 t/ha + PM 2 t/ha), $\mathrm{T}_{10}$ : $(100 \% \mathrm{RDF}+\mathrm{FYM} 5 \mathrm{t} / \mathrm{ha}+\mathrm{PM} 2$ t/ha + Rhiz.), $\mathrm{T}_{11}:(100 \% \mathrm{RDF}+\mathrm{FYM} 5 \mathrm{t} / \mathrm{ha}$ + PM $2 \mathrm{t} / \mathrm{ha}+$ Rhiz. + VC $2 \mathrm{t} / \mathrm{ha})$ in three replications. Five plants were randomly selected for taking all observations and analysis for yield quality estimation. The grain yield was worked out on net plot yield. The analysis and interpretation of data were completed by using OPSTAT developed by CCS HAU, Hisar and as per randomized complete block design.

\section{Results and Discussion}

\section{Plant height (cm)}

Data regarding the effect of organic, inorganic, and biofertilizers on plant height of barley at various growth stages have been summarized in Table 1 . The critical observation of data revealed that significantly taller plants were observed with the application of $100 \% \mathrm{RDF}+\mathrm{FYM} 5 \mathrm{t} / \mathrm{ha}+\mathrm{PM}$ $2 \mathrm{t} / \mathrm{ha}+$ Rhiz. + VC $2 \mathrm{t} / \mathrm{ha}$ at 30, 60, $90 \mathrm{DAS}$, and also at harvest as compared with other treatments. However, it remained at par with application of $100 \%+$ FYM 5 t/ha + PM 2 t/ha + Rhiz. at all crop growth stages. Significantly minimum plant height was recorded in the control treatment. 
Table.1 Effect of integrated nutrient management on growth studies of Barley

\begin{tabular}{|c|c|c|c|c|c|c|c|c|c|c|c|c|c|c|}
\hline Treatments & & $\begin{array}{l}\text { Plant height } \\
(\mathrm{cm})\end{array}$ & & & & & $\begin{array}{c}\text { Number of } \\
\text { tillers/m² }\end{array}$ & & & $\begin{array}{c}\text { Dry weight } \\
\text { g/m2 }\end{array}$ & & & $\begin{array}{c}\text { Grain } \\
\text { yield }\end{array}$ & $\begin{array}{c}\text { Straw } \\
\text { yield }\end{array}$ \\
\hline & $\begin{array}{c}\text { 30 } \\
\text { DAS }\end{array}$ & 60 DAS & $\begin{array}{c}90 \\
\text { DAS }\end{array}$ & $\begin{array}{c}\text { At } \\
\text { harvest }\end{array}$ & 30 DAS & 60 DAS & 90 DAS & $\begin{array}{c}\text { At } \\
\text { harvest }\end{array}$ & $\begin{array}{c}30 \\
\text { DAS }\end{array}$ & 60 DAS & $\begin{array}{c}90 \\
\text { DAS }\end{array}$ & $\begin{array}{c}120 \\
\text { DAS }\end{array}$ & (q/ha) & (q/ha) \\
\hline T1 & 17.33 & 33.83 & 71.97 & 80.14 & 187.33 & 265.00 & 303.00 & 270.33 & 318 & 2127 & 5000 & 7133 & 27.33 & 43.33 \\
\hline $\mathbf{T} 2$ & 20.33 & 37.33 & 75.25 & 84.60 & 196.00 & 286.00 & 328.67 & 296.00 & 417 & 2650 & 5533 & 8600 & 36.65 & 50.00 \\
\hline T3 & 18.80 & 35.17 & 73.63 & 82.63 & 189.67 & 268.00 & 307.00 & 278.33 & 373 & 2217 & 5250 & 7533 & 30.43 & 47.33 \\
\hline T4 & 19.88 & 36.03 & 74.21 & 83.28 & 190.67 & 272.00 & 312.00 & 282.00 & 381 & 2300 & 5300 & 8067 & 32.03 & 49.00 \\
\hline T5 & 19.93 & 36.03 & 74.60 & 84.00 & 192.00 & 276.00 & 317.00 & 286.00 & 391 & 2433 & 5313 & 8200 & 33.00 & 49.67 \\
\hline T6 & 19.98 & 36.48 & 74.80 & 84.03 & 194.00 & 282.00 & 322.00 & 290.33 & 403 & 2583 & 5467 & 8500 & 34.33 & 50.67 \\
\hline $\mathbf{T 7}$ & 20.23 & 38.23 & 75.97 & 85.52 & 203.00 & 288.33 & 338.33 & 307.00 & 472 & 2770 & 5750 & 9033 & 38.00 & 52.00 \\
\hline T8 & 20.21 & 38.00 & 75.30 & 84.53 & 198.00 & 287.00 & 333.00 & 302.00 & 450 & 2733 & 5627 & 8700 & 37.17 & 51.83 \\
\hline T9 & 20.44 & 38.28 & 77.04 & 85.83 & 207.00 & 292.00 & 345.00 & 312.00 & 502 & 2783 & 5833 & 9133 & 38.79 & 52.67 \\
\hline T10 & 21.27 & 39.03 & 78.30 & 86.83 & 210.00 & 297.00 & 351.00 & 316.00 & 557 & 2930 & 6017 & 9200 & 39.67 & 53.00 \\
\hline T11 & 21.90 & 41.33 & 81.29 & 90.00 & 212.00 & 303.00 & 355.00 & 322.00 & 583 & 3147 & 6217 & 9500 & 42.17 & 54.00 \\
\hline CD@5\% & 1.22 & 3.00 & 3.00 & 3.38 & 4.28 & 4.47 & 4.50 & 3.71 & 72 & 354 & 378 & 347 & 2.91 & 1.92 \\
\hline
\end{tabular}

Table.2 Effect of integrated nutrient management on yield attributes of barley

\begin{tabular}{|l|l|l|l|c|c|}
\hline Treatments & \multicolumn{3}{l}{ Leaf area index } & \multirow{2}{*}{ Net returns } & \multirow{2}{*}{ B;C Ratio } \\
\cline { 2 - 4 } & 30 DAS 60 DAS 90 DAS & & \\
\hline T1 & 1.24 & 2.50 & 1.81 & 25,366 & 0.96 \\
\hline T2 & 1.33 & 1.24 & 1.94 & 38,242 & 1.32 \\
\hline T3 & 1.26 & 2.56 & 1.84 & 29,231 & 1.04 \\
\hline T4 & 1.28 & 2.62 & 1.88 & 31,513 & 1.10 \\
\hline T5 & 1.30 & 2.71 & 1.89 & 32,506 & 1.11 \\
\hline T6 & 1.31 & 2.79 & 1.91 & 34,570 & 1.18 \\
\hline T7 & 1.36 & 2.98 & 2.03 & 39,560 & 1.31 \\
\hline T8 & 1.34 & 2.92 & 1.98 & 39,005 & 1.33 \\
\hline T9 & 1.38 & 3.01 & 2.07 & 40,992 & 1.37 \\
\hline T10 & 1.40 & 3.08 & 2.13 & 42,206 & 1.40 \\
\hline T11 & 1.43 & 3.14 & 2.18 & 44,912 & 1.43 \\
\hline CD @ 5\% & $\mathbf{0 . 0 2}$ & $\mathbf{0 . 0 4}$ & $\mathbf{0 . 0 3}$ & $\mathbf{2 0 0 5}$ & $\mathbf{0 . 0 7}$ \\
\hline
\end{tabular}


The increase in plant height might be due to improved soil properties with the application of organic manures like farmyard manure, poultry manure, and vermicompost. These results conform to the results of Dewal (1998).

\section{Number of tillers $/ \mathrm{m}^{2}$}

The data in table 1 revealed that application of $100 \% \mathrm{RDF}+\mathrm{FYM} 5 \mathrm{t} / \mathrm{ha}+\mathrm{PM} 2 \mathrm{t} / \mathrm{ha}+$ Rhiz. + VC 2 t/ha attained significantly more number of tillers $(212.00,303.00,355.00$ and $322)$ at 30, 60, 90 and at harvest. This treatment proved significantly superior to the rest of the treatments whereas at par at 30 DAS, 90 DAS under the application of $100 \%$ RDF + FYM 5 t/ha + PM 2 t/ha + Rhiz. The minimum number of tillers i.e. (187.33, 265.00, 303.00, and 270.33) per meter square plant was recorded in control. These findings are following the results of Chavarekar et al., (2013).

\section{Dry weight $\mathrm{g} / \mathrm{m}^{2}$}

The data on dry weight was recorded at 30 , 60, 90 DAS, and at harvest are presented in Table 1. Application of $100 \%$ RDF + FYM 5 t/ha + PM 2 t/ha + Rhiz. + VC 2 t/ha attained significantly more dry weight $(583,3147$, 6217, and $9500 \mathrm{~cm}$ ) among all treatments. However, it was found at par with $100 \%$ RDF + FYM 5 t/ha + PM 2 t/ha + Rhiz. At all crop growth stages.

Minimum dry weight $(318,2127,5000$, and 7133) was recorded in control. This might be because the addition of FYM, vermicompost, chemical fertilizer and inoculation of biofertilizer in conjunction with all necessary macro and micronutrients and their uptake by the crop and as a resulted effect of higher dry weight and their translocation in plant parts favored which growth and ultimately the value of all yield parameters. Similar findings were also recorded by Nehra et al., (2001).

\section{Leaf area index}

Leaf area index is an important growth index determining the capacity of the plant in rapping solar energy for photosynthesis. The data on the leaf area index of barley at various growth stages have been summarized in Table 2. The data revealed that the leaf area index, in general, was enhanced by different treatments with the advancement of plant growth until harvest stage under all treatments. The different treatments of nutrient management significantly influenced the leaf area index at all growth stages. The screening of data revealed that application of $100 \%$ RDF + FYM 5 t/ha + PM 2 t/ha + Rhiz. + VC 2 t/ha (T11) attained significantly maximum leaf area index $(1.43,3.14$, and 2.18) among all other treatments at 30,60 and 90 DAS, respectively followed by the application of $100 \% \mathrm{RDF}+\mathrm{FYM} 5 \mathrm{t} / \mathrm{ha}+\mathrm{PM}$ $2 \mathrm{t} / \mathrm{ha}+$ Rhiz. Thus, increased availability of macro and micronutrients improved the growth of the crop Ghosh et al., (2003).

\section{Grain yield (q/ha)}

Grain yield is the principal criterion for evaluating the efficiency of various growth factors because the ultimate effects of experimental variables are reflected in the crop yield. Grain yield is the function of effective tillers, spike length, number of grains per spike, and grain weight. The data on the grain yield has been presented in Table 1. Different treatments have a significant effect on grain yield. Application of $100 \%$ RDF + FYM 5 t/ha + PM 2 t/ha + Rhiz. + VC 2 t/ha gave maximum grain yield (42.17) which is statistically at par with $100 \% \mathrm{RDF}+$ FYM 5 t/ha + PM 2 t/ha + Rhiz. and significantly higher grain yield than other treatments. Whereas, minimum grain yield was recorded in control (27.33). It is well known that the addition of FYM separately and in combination with RDF could increase the micronutrient concentration and the 
adsorption power of soil for cations and anions particularly phosphates and nitrates and they were released slowly for the benefit of the crop during the entire growth period (Chesti et al., 2013).

\section{Straw yield (q/ha)}

The data on the effect of treatments on straw yield have been presented in Table 1 . Different treatments have a significant effect on the significant effect on straw yield. The application of $100 \% \mathrm{RDF}+\mathrm{FYM} 5 \mathrm{t} / \mathrm{ha}+\mathrm{PM}$ $2 \mathrm{t} / \mathrm{ha}+$ Rhiz. + VC $2 \mathrm{t} / \mathrm{ha}$ recorded maximum straw yield (54.00) which was statistically at par with $100 \% \mathrm{RDF}+\mathrm{FYM} 5$ t/ha + PM 2 t/ha + Rhiz. and gave significantly lowest straw yield was observed in the control treatment (43.33). A significant increase in straw yield could be due to greater accumulation of dry matter right from the early stage of crop growth and 120 days under increased photosynthetic efficiency and nutrient accumulation. Similar findings were reported by Shejbalova et al., (2014).

\section{Economics}

The data on economic parameters as influenced by different treatments has been given in table 2 . The data revealed that net returns increased consistently and significantly with increasing levels of different fertilizers. The application of $100 \%$ $\mathrm{RDF}+\mathrm{FYM} 5 \mathrm{t} / \mathrm{ha}+\mathrm{PM} 2 \mathrm{t} / \mathrm{ha}+$ Rhiz. + VC 2 t/ha resulted in significantly highest net returns of Rs. 44912 and benefit-cost ratio (1.43) as compared to other treatments. However, it remained at par with the application of $100 \% \mathrm{RDF}+\mathrm{FYM} 5 \mathrm{t} / \mathrm{ha}+\mathrm{PM}$ $2 \mathrm{t} / \mathrm{ha}+$ Rhiz. and $100 \% \mathrm{RDF}+\mathrm{FYM} 5 \mathrm{t} / \mathrm{ha}$ + PM 2 t/ha. Significantly the lowest net return was recorded in control. Thereby indicating that manure application along with biofertilizers become progressively more profitable.
In conclusion the application of $100 \% \mathrm{RDF}+$ FYM 5 t/ha + PM 2 t/ha + Rhiz. + VC 2 t/ha significantly increased growth, yield attributes and yield of barley. Significantly higher net returns and benefit cost (1.43) were observed with the application of $100 \%$ RDF + FYM 5 $\mathrm{t} / \mathrm{ha}+\mathrm{PM} 2 \mathrm{t} / \mathrm{ha}+$ Rhiz. + VC $2 \mathrm{t} / \mathrm{ha}$. However, benefit cost ratio remained at par with the application of $100 \%$ RDF + FYM 5 t/ha + PM 2 t/ha + Rhiz. (1.40) and also in $100 \% \mathrm{RDF}+\mathrm{FYM} 5 \mathrm{t} / \mathrm{ha}+\mathrm{PM} 2$ t/ha (1.37).

\section{References}

Anonymous. 2016. Package and practices for Rabi crops of Punjab. Punjab Agricultural University Ludhiana. pp. 20

Chaudhary, D.R., Bhandari, S.C., and Shukla, L.M. 2004. Role of vermicompost in sustainable agriculture. Agriculture Review. 25 (1): 29-39

Chavarekar, S., Thakral, S.K. and Meena, R.K. 2013. Effect of organic and inorganic nitrogen fertilizers on the quality of barley (Hordeum vulgare L.). Annals of Agriculture Research. 34 (2): 134-137.

Chesti, M.H., Kohli, Anshuman, and Sharma, A.K. 2013. Effect of integrated nutrient management on yield of and nutrient uptake by wheat (Triticum aestivum L.) and soil properties under the intermediate zone of Jammu and Kashmir. Journal of the Indian Society of Soil Science. 61: 1-6.

Dewal, G.S. 1998. The response of barley (Hordeum vulgare L.) to varying levels of sulfur and FYM. M.Sc. (Ag.) Thesis, Rajasthan Agricultural University, Bikaner. pp 87-88

Ghosh, P.K., Bandyopadhyay, K.K., Tripathi, A.K., Hati, K.M., Mandal, K.G., and Misra, A.K. 2003. Effect of integrated management of farmyard manure, phosphor compost, poultry manure 
and inorganic fertilizers for rainfed sorghum (Sorghum bicolor) in vertisols of central India. Indian Journal of Agronomy. 48(1): 48-52.

Grant, D.J. 2000. Nitrogen fertilization of dry land malt barley for yield and quality. Fertilizer Facts No. 24.

Nehra, A.S., Hooda, I.S., and Singh K.P. 2001. Effect of integrated nutrient management on growth and yield of wheat (Triticum aestivum L.). Indian Journal of Agronomy. 46: 112-117.

Shejbalova, S., Cerny, J., Vasak, F., Kulhanek, M., and Balik, J. 2014. Nitrogen efficiency of spring barley in a long-term experiment. Plant Soil Environment. 60(7): 291-296.

\section{How to cite this article:}

Ravinder Singh, Kamalesh Kumar and Harpreet Singh. 2020. Agronomic Executability of Barley under a Combined Approach of Nutrient Management in Punjab. Int.J.Curr.Microbiol.App.Sci. 9(09): 1832-1837. doi: https://doi.org/10.20546/ijcmas.2020.909.230 